\title{
Article
}

\section{The Youth Appeal of Far-Right Music Festivals}

\author{
Pam Nilan
}

check for

updates

Citation: Nilan, P. The Youth Appeal of Far-Right Music Festivals. Youth 2021, 1, 14-26. https://doi.org/ $10.3390 /$ youth 1010003

Academic Editor: Todd Michael Franke

Received: 28 September 2021

Accepted: 25 October 2021

Published: 2 November 2021

Publisher's Note: MDPI stays neutral with regard to jurisdictional claims in published maps and institutional affiliations.

Copyright: (C) 2021 by the author. Licensee MDPI, Basel, Switzerland. This article is an open access article distributed under the terms and conditions of the Creative Commons Attribution (CC BY) license (https:/ / creativecommons.org/licenses/by/ $4.0 /)$.
Alfred Deakin Institute, Deakin University, 2600 Melbourne, Australia; Pam.Nilan@deakin.edu.au

\begin{abstract}
This article explores an important, yet infrequently explored, topic in youth studies: far-right festivals. Drawing upon contemporary international examples, this article suggests the powerful imagery of embodied militancy in far-right festivals may cut through to potential young recruits, especially young men, on a visceral and emotional level. They experience a strong sense of nationalist heritage, cultural belonging and radical political identity. Youth may be attracted to the far-right through festivals because they seem to be an exciting space to express resistance against the mainstream, including hatred for ethnic minorities. There is an active process of becoming that takes place. Through collectively lived experience, young people, especially young white men, are guided towards right-wing extremist membership. Such events offer not only a powerful face-to-face experience for youth, but later become a compelling digital recruitment tool, targeted at young people, when photos and videos of the festival are uploaded on social media.
\end{abstract}

Keywords: far-right festivals; music; youth recruitment; offline-online

\section{Introduction}

Across many countries the far-right is on the rise, and incidences of extreme right-wing terrorism have grown [1-4]. Young people, particularly young men, have increasingly been drawn to far-right groups [5-7]. The far-right appears to offer 'a space to express anger, rebellion and resistance against the mainstream' [8] (p. 356). Teenagers and young adults are the primary targets of far-right recruitment. Karl Mannheim argued that young people aged 15-25 are especially likely to become agents of political change since they come to the sphere of politics as fresh new contacts [9]. It is unsurprising to find that far-right membership typically drops off after the age of 30 [10].

Male youth in precarious employment might find stepping up to join a proud band of white supremacists is compensatory [11]. For example, right-wing extremist young men in the UK explained their initial recruitment in terms of getting recognition for their sense of victimhood. They were lured by the promise of reclaiming their relative privilege as young white men. They embraced the idea that non-white immigrants, especially Muslims, were the main enemy, sinister invaders of their land and culture [12]. Similarly, researchers Storm, Pavlovic and Franc found that attraction to extremism was most evident among young Europeans who felt they lacked power, both politically and over their own lives [13] (p. 126).

They perceived injustice and inequality in subjective terms. Their situations arise from deeper economic and political changes, but the far-right invites them to see cultural invasion and abrogation of entitlement. For some young people, far-right membership may represent a subcultural home where they are welcomed and understood by equally angry people who speak the same language and seem to hold the same values and ideals. A sense of neo-tribal sociality and solidarity grows as they become radicalised. That solidarity was also forged online. A notable Canadian study found that exposure to extremist material was intensified for young recruits by back-and-forth interaction between the digital and the face-to-face. The linked online-offline engagement amplifies the sense of belonging to a community of the like-minded [14]. In short, the prevailing 'cultural imaginary' of far-right youth practices needs to be carefully understood [15] (p. 228). 
To better understand the appeal of the far-right to youth, Askanius advises looking beyond the formal political sphere, and traditional propaganda, to the field of entertainment [16] (p. 20). Miller-Idriss and Grafe-Geusch similarly recommend that to grasp the engagement of Western youth with the far-right, we should examine cultural expressions at the 'peripheries' [17]. One of those peripheral sites is the far-right festival, the topic of this article. Firstly, far-right festivals are far from peripheral when it comes to profits. They make millions in revenue for far-right extremists [18]. Across six countries, Finland, France, Germany, Sweden, the UK and the US, music concerts and festivals were estimated to generate up to 1.8 million British pounds a year [19]. Secondly, far-right groups use festivals to disseminate propaganda, fundraise, network and recruit, locally and across borders.

\section{Consolidation of Far-Right Youth Identity}

It is well-established that a live music festival is an important site for forming and consolidating youth identities [20,21]. For instance, live music actively involves the audience [22], with musicians and event attendees sharing the temporal and spatial conditions of the gig $[23,24]$. Studying Bruce Springsteen fans, Cavicchi found 'descriptions of transformation' following attendance at live performances that mirrored narratives of religious conversion [25] (p. 43). The fans were deeply affected by the experience. As Sara Ahmed writes of affect-'it is a question of what sticks, of what connections are lived as the most intense or intimate, as being closer to the skin' [26] (p. 33). Young festival attendees not only make sense of the live music viscerally, by reference to their own lives, but also make sense of their lives culturally, through the music.

Along those lines, the festival experience may be understood as a 'journey' of the individual self [27], where the collective mood is fuelled by the materiality of the festival as a 'symbolic microstate' [28] (p. 314). For instance, the outdoor setting of a far-right festival may be intentionally evocative of nationalist fervour [29]. In that context, attendees absorb information about what it is to be a fan of a music genre such as NSBM (National Socialist Black Metal), for example, and how to show their allegiance to neo-Nazism and talk about it productively with like-minded peers [30]. The experiential nature of that enculturation process resonates with Howard Becker's account of how new users of marijuana learn to be recognised as marijuana-users through affiliation and initiation into the cultural practices of the scene [31]. It also echoes Loïc Wacquant's study of how young men become boxers by forging pugilistic dispositions in the setting of the gym [32].

The festivals described below attract both male and female young attendees, yet males outnumber females, probably due to the hard genres of music played $[33,34]$, and the popular fight competitions [35]. Moreover, men dominate the ranks of far-right supporters [3]. Young women appear to attend the festivals most often with a boyfriend or partner. Traditional gendered understandings are central to right-wing discourse. Women are primarily regarded as girlfriends, wives and mothers who will reproduce the white nation. Or they are regarded as sex objects. The prevailing discourse deems them irrelevant to the important quests of world-saving men. Feminism is almost always repudiated while the regulation of women's bodies is promoted, often under the guise of protection.

Far-right festivals are coded to appeal to the sense of 'aggrieved entitlement' many young white men seem to carry [36] (p. 454).Coming to support the far-right may represent compensation for white masculinity as the certainties of patriarchal history are challenged [11], and socio-economic precarity increases [37]. Alienated young white men symbolically achieve hyper-masculinity by conducting a populist discourse of hate against immigrants, people of colour, feminists, queers, Muslims and/or the greedy and corrupt elite [3].

Andrew Marantz describes US Far Right adherents as alienated young men full of rage and thereby ripe for the shaping by white supremacist influencers. For example, at a right-wing gathering in the US, Marantz talked to a young Proud Boys member, who said, "[now] I'm proud to be white ( . . ) Being a white cis male is the worst thing you can be. Like Gavin [McInnes] always says, why should I apologize for being who I am?" [38] (p. 22). 
According to Raewyn Connell, the young man who violently acts out aggrieved entitlement 'puts together a tense, freaky facade, around a claim to power where there are no real resources for power' [39] (p. 160). In Scandinavia, one young man told a researcher, 'being a Nazi in a country like Sweden is probably the worst thing you could be (...) And since I wanted to be bad-really bad-I decided to be a Nazi' [40] (p. 208). Neo-Nazi groups offer 'an idealised model of white masculinity, based on nostalgia for a time that has never existed' [11] (p. 69). The endgame is a masculinist, white supremacist utopia; a future in which they will be the rulers. Aryan warrior myths have provided fantasy fodder for not only the German Third Reich but for contemporary Neo-Nazi groups across Europe, North America and Oceania [41]. Images of the powerful hero/warrior grab the attention of youth reared on a cultural diet of fantasy in films, TV series and video games. For example, in video games, from Assassins Creed to Secret Government, a lone vigilante with exceptional abilities goes to war against the proxy forces of a sinister conspiracy. Neo-Nazi groups typically draw on a heady mix of 'Nordic mythology, Tolkienesque traditionalism and hyperbolic medievalism' to construct the ideal of their Aryan activist foot-soldiers [42] (p. 1011).

Joining a far-right group may seem attractive for young men seeking heteronormative brotherhood, sanctioned violence and the position of hero. To that end, male bodies matter. Throughout military history, the ideal soldier has always been a young man with a strong body. Far-right propaganda celebrates a youthfully militant white masculinity [43]. For instance, a standout image of the US Capitol Hill invasion in 2021 was well-built QAnon adherent Jake Angeli (Yellowstone Wolf). At the head of the mob, he howled at phone cameras wearing 'a horned helmet, facepaint and skimpy furs that showed off his Viking tattoos'. As analyst Josh Elliot points out, that made Angeli an instant far-right star. His compelling muscular male warrior image flew around the world in seconds, provoking millions and millions of 'likes', comments, memes and so on [44].

Music has long spread far-right ideology, serving both as a tool to attract young people and a means of expressing the identity of those already committed [45-48]. In the words of a member of neo-Nazi band Flak, 'music is the best [recruitment] leaflet' [49]. Key features of the music are directly connected to the nature of the politics [50], and geared to recruitment through consumption. Bulli found the highest emotional peaks are reached for young Germans during international far-right festivals because they engage the cultural imaginary of a global white supremacy movement [51] (p. 222). In a similar vein, Westberg found white supremacist discourse in the Swedish Neo-Nazi movement to be persuasive for young recruits, not because the images, sound and text relied on 'rational' argument and ideas, but because they provoked intense emotional response. Far-right festivals serve as what Westberg calls discursive gateways to right-wing extremist ideology [52]. We know that social movements and protest actions succeed best when they provide high points 'awash with emotion' [53] (p. 58).

That does not imply that all young people who attend a far-right festival will automatically sign up to a far-right group or movement. Rather, the idea of recruitment here recognises that youth rarely have static identifications with the extreme right wing. They engage multiple-layered affiliations that ebb and flow in the offline-online environment [16]. A festival is never just a face-to-face experience in a single location. Large-scale festivals today are branding practices that traverse the offline and online worlds. Although the festivals are held in different countries, they are advertised on the same online and social media networks to reach a transnational audience of far-right sympathizers. In my observation, festival advertising attempts to appeal across the various far-right factions, emphasizing white supremacy and anti-elite discourses, rather than issues of only national interest. There may well be young people who attend or virtually follow the festivals described here, since that is an affordance of the social media that governs the festival space.

Social media work through commodifying the festival experience 'in its totality, from its material expressions to its affective attachments' [28] (p. 287). That totality includes 
digital curation, both during the event and after the event. For example, attending fans, and those unable to attend, can follow the festival in real time on social media such as Twitter. To enhance that temporal online loyalty, festival organisers generate festival playlists and digital and still photo uploads of performances [54]. Thus, "[far-right] festivals are advertised through social media. Afterwards, photos and videos from those events are shared with their followers again, creating a loop or connection beyond the temporary offline action" [55] (p. 73).

Stirring representations are uploaded to digital media and further merchandising opportunities are offered. Politically, organisers aim to recreate the symbolic microstate of the festival in the digital realm. That is far from trivial. Ekman emphasises the communicative potency of uploaded far-right videos of live events [56]. Such uploads effectively disseminate the extremist basics — white supremacist, misogynist and xenophobic material [57,58]. They can bleed through into mainstream internet culture and political discourse to subtly cement the racialised politics of hate [16] (p. 32). Digital media works according to an 'attention economy' [59]. The more online attention you get, the more effective is your reach. Music tracks, photos and footage from far-right music festivals are curated to consolidate existing youth support and appeal to newcomers.

It should be noted that the festivals described below were feted as international events. To that end, far right network advertising at the broadest level was in English-clearly operating as a lingua franca. Yet there were other social media networks of a local nature where the same festival advertising and live coverage was in German, Russian, Swedish and French and so on. That indicates more than anything the ubiquity of English as one of the main languages on the internet. It was also the case that broad festival advertising and coverage, where it was in English, features extensive use of far-right symbols and logos.

\section{Methodology}

The examples below come from documented far-right music festivals that later featured as representations online. In methodological terms this represents a form of qualitative analysis of existing content $[60,61]$. The approach is often applied in studies conducted through media sources of crime phenomena. In that approach, media sources are treated as repositories of cultural knowledge, which constitute an account of the phenomenon. For this paper, a review of literature relevant to the topic of this paper guided the sampling of instances of far-right festivals and their later uploads. The examples enabled the researcher to discern a sense of the deeper social pattern of potential and actual youth involvement. As with any such analytical endeavour, many more sources were identified than could be effectively used. The instances considered below exemplify the far-right festival offline-online relationship as a two-sided recruitment tool aimed at young people, especially young white men.

\section{Results: Far-Right Music Festivals}

Ethnomusicologist Kirsten Dyck argues that far-right music festivals constitute direct ideological outreach to young people through music and associated activities. Online platform providers facilitate the subsequent sale of music and merchandising, further extending the recruitment potential among young fans. A festival featuring music can directly inform an identifying sense of place and time for young attendees. It can 'evoke and organize collective memories and present experiences of place with an intensity, power and simplicity unmatched by any other social activity' [34] (p. 3).

Music line-ups are vitally important for far-right festival success. Typical genres include white power ballads [62], Rechstrock [51], neo-Nazi punk [63], hyper-nationalist rap [64] and National Socialist Black Metal-NSBM [65]. NSBM is now an important aesthetic/affective signature of many neo-Nazi and white supremacist groups. The sound is loud and hard. Vocals involve howling, screaming or growling, which is typical of extreme metal. Lyrics proclaim the violent values of Nazism, Aryan superiority, and 
genocide; with reference to Scandinavian mythology. In short, music festivals are important for building a collectively held cultural imaginary that fuels extreme right-wing identity.

In the United States, Reid and Valasik argue that far-right music festivals allow the overt expression of a neo-Nazi social identity that would be shamed and stigmatised in other spaces [66] (p. 89). They give the examples of Hammerfest, Nordic Fest and the Rocky Mountains Heritage Fest. Hammerfest is one of the largest white power music concerts held in the United States, showcasing international neo-Nazi bands. It draws fans from across the country, as well as from Canada, the UK and Europe. Nordic Fest is a yearly event for white supremacists in Kentucky. It includes 3 days of white power music, camping, drinking, racist speeches, cross burnings and other rituals. The Rocky Mountains Heritage Fest is a popular 1-day festival featuring big-name hate-rock bands.

Reid and Valasik initially make a comparison between youthful attendees at US far-right festivals and young cosplayers flocking to the convivial space of a ComiCon, where they put on and take off the fantasy identities of their favourite characters. Yet subsequently the same authors question whether that comparison holds true for young attendees at far-right festivals, who may be rapidly drawn further down the rabbit-hole of political extremism by subsequently following the lead of far-right influencers and chat-room convenors online. In other words, they progressively take on an extreme identity of hate that cannot be slipped on and off like a cosplay character [66]. One of the things that far-right festivals do is let young people know what it means to be a far-right supporter or neo-Nazi. They not only learn the lexicon and the mythology but the corporeal grammar of membership. The informal festival pedagogy of how to be a young male far-right supporter is enhanced by the increasing popularity of MMA fights [67]. The fights not only increase profits, but enhance the aura of tough, fit masculinity that the far-right attempts to cultivate.

\subsection{Rock Gegen Uberfremdung-Germany}

In the summer of 2017, 6000 people, mostly young white and male, attended the neoNazi music festival Rock gegen Uberfremdung (Rock against Excessive Foreign Immigration) in the town of Themar in Thuringia, Germany. A local right-wing politician provided a plot of land for the festival. It was estimated to be the largest right-wing extremist festival of 2017 in Europe, and was later acknowledged to be similar to a playlist of the extreme-right scene, drawing together prominent far-right activists, members of violent white supremacist networks like the Hammerskins, and speakers linked to neo-Nazi micro-parties and the extreme-right mixed martial arts scene [18].

The festival line-up included music performances, dance parties, MMA fights, workshops, speeches and merchandise launches.

Young people came for bands such as Stahlgewitter (steel weight), Die Lunikoff Verschwörung (the Lunikoff conspiracy-Lunikoff is the pseudonym of German neo-Nazi musician Michael Regener), Sleipnir (the eight-legged horse of Odin), TreueOrden (order of loyalty), Blutzeugen (martyrs or blood-begotten), Flak (anti-aircraft gun) and Uwocaust (alludes to the Holocaust). Stahlgewitter and Sleipnir are bands affiliated to the transnational Blood \& Honor organisation, which was banned in Germany in 2000. Blut und Ehre (Blood and Honour) was a Hitler Youth slogan. There is no doubt that young European attendees were not only present for festival performances by those extreme right bands, but danced as they played, sang along, gave Nazi salutes at the right moment, photographed the band, downloaded their songs, bought their merchandise, posted about them on social media, and talked knowledgeably about them to other attendees. All that attests to awareness of the neo-Nazi symbolism such bands employ and the political claims that underpin their macho posturing. In that sense we might describe Rock gegen Uberfremdung as a crucible of learning in which a young white male might well make the jump from black metal fan, for example, to supporter of the far-right. It could seem like a move into more extreme iconoclasm; one where the stamp of stigma feels exciting and self-defining. Kimmel argues that youth are often first attracted to the far-right by iconoclastic music and the partying that 
goes along with it [40]. Subsequently, they follow what they see as a bunch of charismatic renegades. Only later do they adopt a right-wing extremist position [10].

Miller-Idriss emphasises the growing popularity of far-right Mixed Martial Arts (MMA) clubs in Germany. She argues that they now constitute a fertile recruiting ground for young white men [67]. The far-right has long celebrated the physical strength of men and enshrined normative masculine ideals of hardness and toughness. Those ideals are amply demonstrated in daytime photos taken at Rock gegen Uberfremdung in 2017. A sequence of still photos depicts an arriving audience of primarily young white men. They are well-muscled with very short hair [68]. They stride together in a menacing, belligerent fashion, rarely smiling, exhibiting the physical persona of 'hard-man' [35].

This is far-right masculine normativity on vivid face-to-face display and readily available for emulation. Copying the corporeal style of far-right masculinity is important for the movement. As pundit Andrew Anglin, creator of the notorious Daily Stormer white supremacist website, wrote to his supporters, "We want to be something that boys fantasize about being a part of ( ... ) People who see us have to want to be us. That means you have to go to the gym" [69].

Anglin wants supporters to be well-muscled white patriots that younger males will find compelling as far-right role models. The men photographed arriving at the Rock gegen Uberfremdung in 2017 match that ideal precisely.

In the photos, arrivals are wearing their right-wing politics literally on their bodies, in clothing coded by symbol and slogan. Popular items are Thor Steiner and Ansgar Aryan hoodies [70]. Some shirts bear provocative slogans such as Sturm auf Themar (Storm in Themar), Merkel muss weg (Merkel must go), HKNKRZ (Hakenkreuz-swastika), Loyalty, Blood, Pride-Join the Invisible Empire (Ku Klux Klan), Weg mit dem NWDO-verbot (Away with the ban on National Resistance Dortmund), Gott mit uns (God with us-Wehrmacht soldiers wore this slogan on their belt buckles), 1933 (the year the German flag first featured the swastika), and All men are created equal, then a few will die in battle and go to Valhalla. Other clothing features right-wing extremist band names-Stahlgewitter, Mjolnir (Thor's hammer), Skrewdriver, Blutzengen, Brainwash, Mortuary, Path of Resistance, FieL-Fremde in eigenen Land (strangers in our own land), Aryans, Life is Pain, Fortress-Defend Europe (band and hit song). Some clothing proclaims the wearer to be a supporter of Arische Bruderschaft (Aryan Brotherhood) and Kampf der Nibelungen (fight of legendary heroes). Kampf der Nibelungen is the largest martial arts event of the right-wing extremist scene in Germany and Europe, held annually in Germany since 2013. The contests do not accept fighters judged to be 'foreigners'. Sponsors of the Kampf der Nibelungen are the martial arts-affiliated men's clothing brands White Rex, Raptor, Black Legion and Pride France; they were also featured as logos on the shirts of some men arriving at the 2017 Rock gegen Uberfremdung festival.

It seems that just by mixing with the arriving crowd, a neophyte could absorbviscerally - knowledge of the bodily capacity necessary to look the part and be the part of a far-right supporter. Yet that 'becoming' does not end with the close of the festival. The sequence of photos at EXIF is just one of the online resources provided after the event. Other resources, including live footage of band performances and MMA fights, available merchandise and music downloads, add to the curated richness of far-right culture that neophyte supporters can access online.

\subsection{Asgardsrei Festival-Ukraine}

While Germany seems to be quite a popular place for far-right festivals, Ukraine is even more popular. Seen by some as a 'playground' for the far-right, festivals in Ukraine are an important part of the European picture [71]. For example, the annual Asgardsrei festival in Kiev has been described as 'a staple on the far-right musical calendar' and 'a place for international far-right extremists to gather and network in an environment far more open to their presence than in many other countries' [72]. Asgardsrei refers to Asgard-the dwelling place of the gods in Norse mythology. It is one of the most popular summer events for far-right extremists in Europe [73]. 
At the 2019 Asgardsrei Festival, the transnational band line-up featured cult-favourite M8Л8TX (originally from Russia). The name M8Л8TX references 88, which is neo-Nazi code for Heil Hitler, $\mathrm{H}$ being the eighth letter of the alphabet. Other bands included Goatmoon (Finland) Der Stürmer ('attacker', an anti-semitic Nazi newspaper-Greece), Wodulf (sounds like Adolf-Greece), Stahlfront (steel front-Germany), Absurd (Germany), Sunwheel (Poland), Selbstmord (suicide-Poland), Dark Fury (Poland), Peste Noire (black deathFrance), Seigneur Voland (medieval term for Satan-France), and Nokturnal Mortum (night of death-Ukraine). The obvious semantic links between these band names-despite their different countries of origin-speak to a transnational far-right movement pre-occupied with historical Nazism, the occult and white supremacy. On one hand, the themes borrow from the traditional mythologies referenced by black/heavy metal music, on the other hand from current directions in the European far-right. It suggests a direct affinity between black/heavy metal and the far-right, inviting young (white) fans into a pan-European subcultural home where they feel welcomed and understood.

During the 2019 Asgardsrei Festival, attendees posted continually to Twitter, Telegram, Instagram, and other social media. Journalist Michael Colborne and fellow researchers followed the Instagram hashtags \#asgardsrei and \#asgardsrei2019. Instagram users with public accounts shared stories, videos and photos. The Bellingcat team downloaded and screenshot public Instagram posts from the festival before they disappeared. There was a flurry of posts when a mixed martial arts (MMA) 'fight night' took place. For example, one attendee wrote on Instagram, 'dozens of spectacular fights and dozens of supporters! First blood is spilled, the wild hunt has begun' [72]. In other words, when the first combatants began to bleed from their wounds, it was regarded as a moment of initiation in the quest for victory. The wording points to the salience of the mythological warrior narrative.

Among live acts at the festival, the Russian/Ukrainian band Akvlt (Adolf cult) performed on stage with candles and torches, backlit by an Aryan victory image in red. The musicians were clad in black, with faces concealed. Backed by a repetitive heavy metal accompaniment they screamed and growled through folkloric paeans to Aryan might. According to Colborne, one attendee wrote about that performance on Instagram; 'esoteric enlightenment through superior firepower!' It should be noted that across Europe there is a ban on swastikas. Nevertheless, ample neo-Nazi, white supremacist imagery was on display at the 2019 Asgardsrei Festival, including the celtic cross, black sun and wolfsangel. Some band performers had swastika tattoos they only revealed on stage. Fans frequently gave Nazi salutes during performances and in the festival environs. By all those means, attendees are made aware of culturally appropriate ways to show their neo-Nazi sympathies. After it was over, the channel administrator for the 2019 festival posted about the event in Ukrainian and English. "Thanks to everybody who visited Asgardsrei 2019", he wrote, adding, 'white brothers from all over the Europe had an awesome time, made new friends and met old ones'. The post finished with the words 'Sieg Heil!'. Satisfied attendees wrote in glowing terms of their transnational festival experience on the neo-Nazi website Iron March (now defunct), for example, "[I] met nice naziboys [sic] from Serbia, Croatia, Sweden, France, Ukraine and Russia', and 'a good opportunity for EVIL NAZIS from all around the globe to meet, listen to god-tier music and have a fucking good time". Those comments hint at the iconoclastic pleasure of belonging to a transnational band of brothers (nice naziboys) who scare people (EVIL NAZIS). The adjective 'god-tier' is a youth slang term meaning the best. On the equally notorious Stormfront website, another attendee wrote that the festival was, 'the best organized gathering of white nationalists in the world. Ukraine is a very favorable country and I think everyone can afford it' [74].

To sum up, youthful attendees found the 2019 Asgardsrei Festival affordable, pleasurable and validating. That might well be true of youth experiences at other, non-political, festivals but the key aesthetic/political themes of the 2019 Asgardsrei Festival were neoNazism and white nationalism. So, to rephrase the claim, the aesthetised neo-Nazism and white nationalism at this festival was judged to be low cost, enjoyable and cosmopolitan, geared to the tastes and budgets of right-wing young Europeans aged 18-35. 


\subsection{Young Flame Fest-Ukraine}

Another far-right festival took place in Ukraine in 2019-the Young Flame Fest. Sponsored by the militant right-wing organisation Azov (Battalion), it sought to attract young white people from all European countries. Journalist Simon Shuster attended the festival, which was held in Kyivan Rus Park, a large-scale tourist re-construction of medieval Kiev. Amid grassy fields, quaint replica half-timbered buildings and performers in national dress, Shuster found thousands of young (white) Europeans enjoying Ukrainian folk music (bagpipes, traditional instruments and costumes) and handcrafts (wood-carving, leatherwork). Attendees were browsing stalls and purchasing merchandise, including white nationalist printed fashion clothing and accessories, magazines and trinkets [75].

There were team fist fights, archery, rugby and weight lifting competitions. Attendees could download freshly minted white power and NSBM music. Political, philosophical and historical lectures on white nationalism were on offer. On the last evening there was a closing ceremony with a large fire event [76]. There were abundant references to neoNazism everywhere at the Young Flame Fest. For example, the Azov flag itself features the Nazi symbol of the wolfsangel. Festival stalls were selling the Azov magazine The Black Sun. The black sun (Sonnenrad) is an old occult symbol taken up by German Nazism [77]. Similarity to Hitler Youth training camps was further reflected in the emphasis on male combat and physical fitness, as well as messages everywhere about the loss of primordial rights due to alleged (alien) invasion of the (proto-European) homeland.

Journalist Shuster spoke with a just-arrived festival attendee from Sweden, Robin, aged in his early 30s. Already a supporter of the far-right back home, Robin said he had learned about the festival from neo-fascist social media, which disseminated evocative crowd photos and live footage from the 2018 event. That points to the strategic nature of Azov digital propaganda, which had more than 38,000 subscribers to the Azov Media YouTube channel in 2019 [78]. In typical uploaded Azov videos, muscular young men are shown taking part in 'ceremonial activities, parades, training and demonstrations, as well as combat' [79] (p. 436).

Robin had been inspired by that digital archive to attend the Young Flame Fest. On arrival, he walked into the symbolically potent physical setting and was ecstatic, "It's hard to explain the surroundings ( ... ) it's surreal-I don't know—it's like something you read about, the great Germany before, like in the 1920s. It's like a great revival of the Indo-European soul, and it's all happening here" [75].

Visual and sensory metaphors evoked for Robin the feeling of a myth-wreathed Aryan identity. He said he was so moved that he signed up on the spot to join the right-wing Azov militia. Since November 2014, Azov (Battalion) has been recognized as a regiment of soldiers serving in the National Guard of Ukraine. Members are from 22 countries, even though the Minsk Ceasefire Agreement does not formally allow foreign fighters to serve in Ukraine's military [71].

In the view of journalist Shuster, the 2019 Young Flame Fest encoded an implicit call to arms-directed at young men seeking glory and heroism through joining a right-wing militia. Robin is an example of a young man who responded immediately to that call.

Following the festival, Robin emailed journalist Shuster with an update on his recruitment, "I'm still at Azov's place. They are treating me like a brother. I work out every day, learn to handle a knife fight, eat well and playing guitar with the guys ( . . ) in a few days I will be transferred" [75].

Among other male recruits, Robin was getting fit and learning how to handle a weapon. He was clearly enjoying membership of the battle-bound band of brothers. Robin's reported phrase 'with the guys' is not incidental. It connotes both young male belonging and emulation.

Edited glimpses of the Young Flame Fest were available during and after the festival. For example, a Twitter photo depicts a casually dressed young, blonde couple filming themselves on a phone as they prepare to enter the festival gates [80]. Both are wearing the official festival black t-shirt; the stylised diving eagle logo of the militia in yellow on 
the front and the militia name in yellow Cyrillic script on the back. The young couple is surrounded by fellow festival attendees, all 'white' and similarly clad, full of excitement in the morning sun. A tree in the background is in full leaf, signalling that the season of high summer matches the joyful exuberance of the youthful crowd pouring in through a large gate in a traditional wooden palisade, with half-timbered watchtowers on either side. From each watchtower hangs an emblematic Azov banner with wolfsangel. In short, the young people in the photo are embellished and framed by far-right symbolism in which European seasons and landscape are entangled.

On the same Twitter site, another posting from Young Flame Fest shows footage of the fire event. Flame-lit figures gyrate to a pounding hard beat of white power rock in front of a huge screen displaying Neo-Nazi symbols, white supremacist phrases and live footage of Azov Battalion members killing Russian troops during the eastern Ukraine conflict. That conflict is not directly related to the transnational field of far-right politics, but it did not seem to matter to the dancing young Europeans from many different countries. Other photos and footage on the same Twitter site depict rapt young spectators at the Young Flame festival watching bare-chested muscular men punching each other. The examples bear out the claim that far-right radicalisation is intensified by back-and-forth interaction between the digital and the face-to-face realms because that dual engagement reinforces, even amplifies, hyper-nationalism and the sense of belonging [14].

\section{Discussion}

As a cultural product, far-right festivals in Europe (and elsewhere) constitute a means through which young attendees can directly engage not only hyper-nationalist content, but hate-filled music, neo-Nazi symbolism and the warrior heroism of MMA. Moreover, the context instils in them the cultural knowledge about what it means to be moved by ultranationalism and xenophobia, and how to publicly display their gendered and racialised support for the cause in clothing choice, tattoos and bodily comportment. As they learn experientially at the festival, they become vitally aware of the Nazi heritage as a point of reference and comparison.

The process of a young white individual becoming a far-right supporter is similar to an informal apprenticeship process in which older members informally school the newcomers [81]. From attending the festival, young people informally gain the tools they need to decipher the experience of the music, the fighting contests and the politics. They assimilate knowledge about listening in a passionate way to the music, about how to talk about white supremacy and ultra-nationalism in acceptable terms, and how their bodies should be styled and comported. They demonstrate (sub)cultural competence by watching live band performances and MMA fights loudly and enthusiastically, by wearing suitably coded clothing and tattoos, and by dancing in a suitably muscular, aggressive way. Thereby, they learn to render a neophyte far-right identity legible for others in the scene, the rightwing extremist movement. It seems that many far-right festival newcomers partake in a cycle of enchantment that often starts with a visceral connection to the music, or to MMA, or both. Over the days and nights of a far-right festival they become thoroughly socialised in what constitutes enjoyment and how to decode and recode what they are experiencing.

Later, engagement with online and social media documentation mediates the festival experience for attendees and for peers who did not attend. That process of digital mediation can help transform initial aesthetic/political attraction into a more elaborate and sustained attachment, possibly leading them to engage in forms of 'digital extremism' [82]. Through that understanding we can more readily grasp the specific cultural product of the far-right festival, and the young people, primarily young white men, who attend, and what they get out of it.

\section{Conclusions}

In concluding this paper, we are reminded that recruits to the far-right often come with a deeply felt sense of aggrieved entitlement against what society is apparently denying 
them. That renders them emotionally susceptible to narratives of discursively legitimised hate and violence. They are encouraged to participate in some form of restorative transformation based on the historical archetype of the warrior or soldier-for-truth. At far-right festivals such as those depicted above, the music, the merchandising and MMA fights reference neo-Nazi symbols and tropes to promote a mythology about proud young heroes defending the besieged white nation/people. That narrative is rendered more affectively potent by its articulation in the full-summer outdoor setting of a festival.

The engagement of young people happens at two levels: the embodied face-to-face experience of the festival, and the virtual experience online that occurs once images and text are uploaded to social media and news media. The physical encounter happens in the moment and is time-bound. The virtual encounter has no time limit. The photos and videos can be viewed again and again, and yet again, as records of actual embodied events. The neophyte can readily remember, or imagine, himself with a band of brothers, honing his masculine body, celebrating neo-Nazism, threatening violence against those deemed invaders. Through the dissemination affordances of digital/social media, discursive resonances, like ripples on a pond, spread out across the screens and feeds of many more potential young recruits to the far-right.

It seems evident that governments, local, regional and national, could do more to directly intervene in the apparent proliferation of far-right festivals in some parts of the Western world. That would not only limit the direct indoctrination of young people in the embodied face-to-face encounter of the festival itself, but prevent amplified representation of that same evocative event in later uploads. At the same time though, interventions of that kind would need to be carefully developed to avoid compromising privacy and civil liberty. This paper indicates some important trends that can be explored and analysed more fully in future research.

Funding: This work was supported by the Australian Research Council under Grant DP200102013.

Institutional Review Board Statement: Not applicable.

Conflicts of Interest: There is no financial interest or benefit that arises from the direct application of the research reported here.

\section{References}

1. Director-General's Annual Threat Assessment. Australian Security Intelligence Organisation, 24 February 2020. Available online: https:/ / www.asio.gov.au/publications/speeches-and-statements/director-general-annual-threat-assessment-0.html (accessed on 17 February 2020).

2. Blee, K.M. Where Do We Go from Here? Positioning Gender in Studies of the Far Right. Politics Relig. Ideol. 2020, $21,416-431$. [CrossRef]

3. Grant, J.; MacDonald, F. The 'Alt-right', Toxic Masculinity and Violence. In Turbulent Times, Transformational Possibilities? Gender and Politics Today and Tomorrow; McDonald, F., Dobrowolsky, A., Eds.; University of Toronto Press: Toronto, ON, Canada, 2020; pp. 368-388.

4. Mudde, C. The Far Right Today; Polity: London, UK, 2019.

5. Buckby, J. Monster of Their Own Making: How the Far Left, the Media, and Politicians Are Creating Far-Right Extremists; Bombardier Books: New York, NY, USA, 2020.

6. McAleer, T. The Cure for Hate: A Former White Supremacist's Journey from Violent Extremism to Radical Compassion; Arsenal Pulp Press: Vancouver, BC, Canada, 2019.

7. Picciolini, C. White American Youth: My Descent into America's Most Violent Hate Movement-and How I Got Out; Hachette: New York, NY, USA, 2018.

8. Miller-Idriss, C. Youth and the Radical Right. In The Oxford Handbook of the Radical Right; Rydgren, J., Ed.; OUP: Oxford, UK, 2018; pp. 348-365.

9. Mannheim, K. The Problem of Generations. In The New Pilgrims: Youth Protest in Transition; Altbach, P., Laufer, R., Eds.; McKay: New York, NY, USA, 1972; pp. 101-138.

10. Simi, P.; Futrell, R. American Swastika: Inside the White Power Movement's Hidden Spaces of Hate, 2nd ed.; Rowman \& Littlefield: New York, NY, USA, 2015.

11. Kelly, A. The Alt-right: Reactionary Rehabilitation for White Masculinity. Soundings 2017, 66, 68-78. [CrossRef]

12. Ebner, J. The Rage: The Vicious circle of Islamist and Far-right Extremism; B. Tauris \& Co.: London, UK, 2017. 
13. Storm, I.; Pavlovic, T.; Franc, R. DARE-Dialogue about Radicalisation and Equality; Report on the relationship between inequality and youth radicalisation from existing European survey datasets. 2020. Available online: http://www.dare-h2020. org/uploads/1/2/1/7/12176018/d4.3.pdf (accessed on 25 September 2020).

14. Gaudette, T.; Scrivens, R.; Venkatesh, V. The Role of the Internet in Facilitating Violent Extremism: Insights from Former Right-Wing Extremists. Terror. Political Violence 2020, 32. [CrossRef]

15. Kølvraa, C.; Forchtner, B. Cultural Imaginaries of the Extreme Right: An Introduction. Patterns Prejud. 2019, 53, 227-235. [CrossRef]

16. Askanius, T. 'I Just Want to be the Friendly Face of National Socialism': The Turn to Civility in the Cultural Expressions of neo-Nazism in Sweden. Nord. Rev. 2021, 42 (Suppl. 1), 17-35. [CrossRef]

17. Miller-Idriss, C.; Grafe-Geusch, A. Studying the Peripheries: Iconography and Embodiment in Far Right Youth Subcultures. In Researching the Far Right: Theory, Method and Practice; Ashe, S.D., Busher, J., Macklin, G., Winter, A., Eds.; Routledge: London, UK, 2021; pp. 323-335.

18. Hume, T.; Bennett, T.; Langston, H. Neo-Nazi Music Festivals Are Funding Violent Extremism in Europe. Vice. 20 September 2021. Available online: https:/ / www.vice.com/en/article/wx533x/neo-nazi-music-festivals-are-funding-violent-extremismin-europe (accessed on 21 September 2021).

19. Harley, N. Music Festivals Make Millions in Revenue for Far-right Extremists. The National News-The World. 8 January 2021. Available online: https:/ / www.thenationalnews.com/world/music-festivals-make-millions-in-revenue-for-far-right-extremists1.1142369 (accessed on 15 September 2021).

20. Bennett, A.; Woodward, I. Festival Spaces, Identity, Experience and Belonging. In The Festivalization of Culture; Bennett, A., Taylor, J., Woodward, I., Eds.; Ashgate: Farnham, UK, 2014; pp. 11-25.

21. Kahn-Harris, K. Extreme Metal: Music and Culture on the Edge; Bloomsbury: London, UK, 2007.

22. Frith, S. Performing Rites: On the Value of Popular Music; OUP: Oxford, UK, 1996.

23. Hesmondhalgh, D. Why Music Matters; Wiley Blackwell: Chichester, UK, 2013.

24. DeNora, T. Music in Everyday Life; Cambridge University Press: Cambridge, UK, 2000.

25. Cavicchi, D. Tramps Like Us: Music and Meaning among Springsteen Fans; New Oxford University Press: New York, NY, USA, 1998.

26. Ahmed, S. Collective Feelings: Or, the Impressions Left by Others. Theory Cult. Soc. 2004, 21, 25-42. [CrossRef]

27. Luckman, S. Location, Spatiality and Liminality at Outdoor Music Festivals: Doofs as Journey. In The Festivalization of Culture; Bennett, A., Taylor, J., Woodward, I., Eds.; Ashgate: Farnham, UK, 2014; pp. 189-205.

28. Gligorijević, J. Rethinking Politics in Contemporary Music Festivals: From Brandscapes to Potentially New Forms of Collectivities. Musicol. Res. 2018, 5, 287-326.

29. Cupers, K. Governing through Nature: Camps and Youth Movements in Interwar Germany and the United States. Cult. Geogr. 2008, 15, 173-205. [CrossRef]

30. Robinson, R. Music Festivals and the Politics of Participation; Ashgate: Farnham, UK, 2015.

31. Becker, H. Becoming a Marihuana User. Am. J. Sociol. 1953, 59, 235-242. [CrossRef]

32. Wacquant, L. Body and Soul: Notebooks of an Apprentice Boxer; Oxford University Press: New York, NY, USA, 2003.

33. Teitelbaum, B.R. Lions of the North: Sounds of the New Nordic Radical Nationalism; Oxford University Press: Oxford, UK, 2018.

34. Dyck, K. Reichsrock: The International Web of White-Power and Neo-Nazi Hate Music; Rutgers University Press: New Brunswick, NB, Canada, 2017.

35. Schiller, K. Masculinities in Martial Arts and Combat Sports-An Interdisciplinary Issue. Sport Hist. 2020, 40, 291-295. [CrossRef]

36. Kalish, R.; Kimmel, M. Suicide by Mass Murder: Masculinity, Aggrieved Entitlement and Rampage School Shootings. Health Sociol. Rev. 2010, 19, 451-464. [CrossRef]

37. Standing, G. The Precariat; Bloomsbury: London, UK, 2011.

38. Marantz, A. Antisocial: Online Extremists, Techno-Utopians, and the Hijacking of the American Conversation; Viking: New York, NY, USA, 2019.

39. Connell, R. Live Fast and Die Young. Aust. N. Z. J. Sociol. 1991, 27, 141-171. [CrossRef]

40. Kimmel, M. Racism as Adolescent Male Rite of Passage: Ex-Nazis in Scandinavia. J. Contemp. Ethnogr. 2007, 36, 207-242. [CrossRef]

41. Hovdkinn, E. The Myths of Norse Mythology. Religion Going Public. 2 May 2016. Available online: http:/ / religiongoingpublic. com/archive/2016/the-myths-of-norse-mythology (accessed on 12 May 2017).

42. McLaren, P. Are Those Whiffs of Fascism that I Smell? Living Behind the Orange Curtain. Educ. Philos. Theory 2020, 52, 1011-1015. [CrossRef]

43. Kusz, K. Winning 'Bigly': Sporting Fantasies of White Male Omnipotence in the Rise of Trump and Alt Right White Supremacy. J. Hate Stud. 2018, 14, 113-136. [CrossRef]

44. Elliott, J. Horn-helmed QAnon Rioter among Far-right 'Stars' in U.S. Capitol Attack. Global News. 8 January 2021. Available online: https:/ / globalnews.ca/news/7563532/fur-horns-helmet-trump-qanon-antifa-capitol/ (accessed on 10 March 2021).

45. Worley, M.; Copsey, N. White Youth: The Far Right, Punk and British Youth Culture, 1977-1987. In Tomorrow Belongs to Us: The British Far Right Since 1967; Copsey, N., Worley, M., Eds.; Routledge: London, UK, 2018; pp. 113-131.

46. Spracklen, K. Nazi Punks Folk Off: Leisure, Nationalism, Cultural Identity and the Consumption of Metal and Folk Music. Leis. Stud. 2013, 32, 415-428. [CrossRef] 
47. Birdsall, C. Nazi Soundscapes: Sound, Technology and Urban Space in Germany, 1933-1945; Amsterdam University Press: Amsterdam, The Netherlands, 2012.

48. Shekhovtsov, A. Apoliteic Music: Neo-Folk, Martial Industrial and 'Metapolitical Fascism'. Patterns Prejud. 2009, 43, 431-457. [CrossRef]

49. Forchtner, B. Fancy a Show? Neo-Nazi Concerts in Germany. CARR-Centre for Analysis of the Radical Right. 24 September 2018 Available online: https://www.radicalrightanalysis.com/2018/09/24/fancy-a-show-neo-nazi-concerts-in-germany/ (accessed on 17 September 2021).

50. Street, J. Music and Politics; Polity: Cambridge, UK, 2017.

51. Bulli, G. The Long Evolution of Extreme Right Music in Italy and Germany. Partecip. E Confl. 2020, 13, 207-231. [CrossRef]

52. Westberg, G. Affective Rebirth: Discursive Gateways to Contemporary National Socialism. Discourse Soc. 2021, 32, 214-230. [CrossRef]

53. Kemper, T.D. A Structural Approach to Social Movement Emotions. In Passionate Politics: Emotions and Social Movements; Goodwin, J., Jasper, J.M., Polletta, F., Eds.; University of Chicago Press: Chicago, IL, USA, 2001; pp. 58-73.

54. Nunes, P.; Birdsall, C. Curating the Urban Music Festival: Festivalisation, the 'Shuffle' Logic, and Digitally-shaped Music Consumption. Eur. J. Cult. Stud. 2021, in press. [CrossRef]

55. Karl, P. Creating a New Normal: The Mainstreaming of Far-Right Ideas Through Online and Offline Action in Hungary. In Post-Digital Cultures of the Far Right; Fielitz, M., Thurston, N., Eds.; Transcript Verlag: Bielefeld, Germany, 2019 ; pp. 67-78.

56. Ekman, M. The Dark Side of Online Activism: Swedish Right-Wing Extremist Video Activism on YouTube. MedieKultur: J. Media Commun. Res. 2014, 30, 79-99. [CrossRef]

57. Richards, I. A Philosophical and Historical Analysis of 'Generation Identity': Fascism, Online Media, and the European New Right. Terror. Political Violence 2019, 1-21. [CrossRef]

58. Deem, A. Extreme Speech: The Digital Traces of \#whitegenocide and Alt-right Affective Economies of Transgression. Int. J. Commun. 2019, 13, 3183-3202.

59. Williams, J. Stand out of Our Light: Freedom and Resistance in the Attention Economy; CUP: Cambridge, UK, 2018.

60. Kort-Butler, L.A. Content Analysis in the Study of Crime, Media, and Popular Culture. In Oxford Research Encyclopedia: Criminology and Criminal Justice; OUP: Oxford, UK, 2016; pp. 1-13. [CrossRef]

61. Altheide, D.; Schneider, C. Qualitative Media Analysis; Sage: Los Angeles, CA, USA, 2013.

62. Grosholz, J.M.; Pieri, Z. 'A Skinhead at Heart with a Hate-Filled Mind': Understanding the Themes Present in the White Power Music Scene. Stud. Confl. Terror. 2020. [CrossRef]

63. Raposo, A.; Bestley, R. Designing Fascism: The Evolution of a Neo-Nazi Punk Aesthetic. Punk Post-Punk 2020, 9, 467-498. [CrossRef]

64. Żuk, P.; Żuk, P. ‘Nation against the System': Nationalist Rap as the Voice of Marginalized Classes and Losers from the Neoliberal Transformation in Poland. Commun. Crit. Cult. Stud. 2021. [CrossRef]

65. Hedge Olson, B. Burzum Shirts, Paramilitarism and National Socialist Black Metal in the Twenty-first Century. Met. Music. Stud. 2021, 7, 27-42. [CrossRef]

66. Reid, S.E.; Valasik, M. Alt-Right Gangs: A Hazy Shade of White; University of California: Oakland, CA, USA, 2020.

67. Miller-Idriss, C. Hate in the Homeland: The New Global Far Right; Princeton University Press: Princeton, NJ, USA, 2020.

68. EXIF. Rock gegen Überfremdung-Themar. EXIF-Recherche et Analyse. 15 July 2017. Available online: https://exif-recherche.org/ ?envira=15-07-2017-rock-gegen-ueberfremdung-themar (accessed on 17 September 2021).

69. Anglin, A. PSA: When the Alt-Right Hits the Street, You Wanna Be Ready. Daily Stormer. 9 August 2017. Available online: https: / / whitelocust.wordpress.com/2017/08/09/psa-when-the-alt-right-hits-the-street-you-wanna-be-ready/ (accessed on 18 February 2021).

70. Miller-Idriss, C. The Extreme Gone Mainstream: Commercialization and Far Right Youth Culture in Germany; Princeton University Press: Princeton, NJ, USA, 2018.

71. MacKenzie, A.; Kaunert, C. Radicalisation, Foreign Fighters and the Ukraine Conflict: A Playground for the Far-Right? Soc. Sci. 2021, 10, 116-132. [CrossRef]

72. Colborne, M. Dispatches from Asgardsrei: Ukraine's Annual Neo-Nazi Music Festival. Bellingcat. 2 January 2020. Available online: https:/ / www.bellingcat.com/news/2020/01/02/dispatches-from-asgardsrei-ukraines-annual-neo-nazi-music-festival/ (accessed on 16 September 2021).

73. Moynihan, C. Heavy Metal Confronts Its Nazi Problem. The New Yorker. 19 February 2019. Available online: https://www. newyorker.com/culture/culture-desk/heavy-metal-confronts-its-nazi-problem (accessed on 15 September 2021).

74. Colborne, M. Most neo-Nazi Music Festivals Are Closely Guarded Secrets-Not This One in Ukraine. Haaretz. 12 December 2019. Available online: https://www.haaretz.com/world-news/europe/.premium-most-neo-nazi-music-festivals-are-closelyguarded-secrets-not-this-one-1.8260218 (accessed on 14 September 2021).

75. Shuster, S. Like, Share, Recruit: How a White-supremacist Militia uses Facebook to Radicalize and Train New Members. Time. 12 January 2021. Available online: https:/ / www.facebook.com/time/posts/10158182970091491 (accessed on 15 March 2021).

76. Der dritte Weg. Ukraine: Young Flame Fest setzt neue Maßstäbe. Der dritte Weg. 9 September 2019. Available online: https: / / der-dritte-weg.info/2019/09/ukraine-young-flame-fest-setzt-neue-massstaebe-videos / (accessed on 23 September 2021). 
77. Goodrick-Clarke, N. Black Sun: Aryan Cults, Esoteric Nazism and the Politics of Identity; New York University Press: New York, NY, USA, 2002

78. The Nexus Between Far-Right Extremists in the United States and Ukraine. CTC Sentinel. April 2020. Available online: https:/ / ctc.usma.edu/the-nexus-between-far-right-extremists-in-the-united-states-and-ukraine/ (accessed on 5 June 2020).

79. Saressalo, T.; Huhtinen, A.-M. The Information Blitzkrieg-'Hybrid' Operations Azov Style. J. Slav. Mil. Stud. 2018, 31, 423-443. [CrossRef]

80. Kuzmenko, O. More Pics from Young Flame festival of Far-right Azov Movement/ National Corps in Kyiv on August 31st. 2 September 2019—Twitter Web App. Available online: https://twitter.com/kooleksiy/status/1168367880045510656/photo/3 (accessed on 14 March 2021).

81. Littler, M.; Lee, B. Digital Extremisms; Springer: New York, NY, USA, 2020.

82. Wacquant, L. Carnal Connections: On Embodiment, Membership, and Apprenticeship. Qual. Sociol. 2005, 28, 441-471. [CrossRef] 